\title{
THE WEB OF INTEREST: THE IMPORTANCE OF FORESTS AND FORESTRY TO CANADA ${ }^{1}$
}

\author{
By LOWELL BESLEY 2
}

Oxf. 906-(71)

The theme of this historic meeting of our two professional societies is "Not by Forestry Alone". It is the purpose of this lead-off general session called "The Web of Interest" to examine how foresters and forestry are working within broadening associations of expertise and knowledge while more and more, public and political forces, and social and economic trends are exerting strong influences on forestry in North America. We have assembled here a distinguished and highly competent group of panelists to discuss these matters with you and we shall introduce them presently. First, however, Mr. Cliff and I have been asked to briefly outline the importance of forests and forestry to the United States and Canada.

When one speaks of Canada, there is a great temptation to cite the imposing statistics of its vast land area and its abundance of most of the important natural resources. Through its leadership in the discovery, development and utilization of its rich energy sources of water power, petroleum, natural gas, coal and uranium, this sparsely populated country has developed into a modern industrial nation. It has converted its storehouse of raw materials into goods and services to become a major trading country-fifth largest in the world. Indeed, over half its exports are highly processed and manufactured products such as newsprint, wood pulp, chemicals, and machinery and transport equipment.

This morning we are concentrating on the forests, how they are interwoven into the economic fabric of the country, and what part we as professional foresters can play in managing these forests for maximum production of goods and services.

First, what is the forest land resource to be managed? Here we must take the broad view of the forest as the producer of successive crops of wood and fibre for industrial use, of game and fish for sport, fur and food, of environment for living and recreation, and of pleasant surroundings for the contemplation of space.

This year Canada is celebrating its first 100 years of Confederation, but it is also looking ahead to the second hundred years. Forecasts for timber production look to a doubling of the annual cut within the next decade or two and a quadrupling by the year 2000 . The demands upon the forest for space and all types of recreation are expanding at a higher rate, and already serious pressures for forest land have developed in local areas and even whole regions of the country.

\footnotetext{
${ }^{1}$ Presented at the Opening Session, Joint CIF-SAF Annual Meeting, Ottawa, Canada, Oct. 16, 1967.

¿ Chairman, Woodlands Research Department, Pulp and Paper Research Institute of Canada.
} 
In total land area, Canada, with its ten provinces and two territories, has only a few million acres more than that of the fifty states of the United States. Its area in forest is nearly half again as large as that in the United States, but its productive forest land is less than a fifth larger. Furthermore, only two-thirds of Canada's productive forest area is considered commercially accessible, and only a third is occupied for timber production.

Whereas nearly three-fourths of United States commercial forest areas are privately owned, private ownership in Canada accounts for only 9 percent of the productive forest area. Furthermore, while four-fifths of the public ownership in the United States is vested in the Federal Government, in Canada the provincial governments control nine-tenths of the $91 \%$ in public ownership.

The management and sale of the public lands in the provinces and of the timber and wood thereon has been under the exclusive jurisdiction of the legislatures of the Provinces ever since Confederation. Most of the provinces early established a policy of encouraging the establishment of wood-using industries by leasing large forested tracts at a nominal annual land rental and charging stumpage for the timber as it was cut. A wide variety of timber lease, licence and sales schemes has been developed over the years, but essentially the province retains ownership of the land and sells the timber.

During the early years timber resources were thought to be inexhaustible. The leasing scheme provided the lumberman with a "buy now-pay later" plan for protecting his investment in plant and equipment, and it provided the hard-pressed provincial treasuries with a source of income as the timber was cut and manufactured into saleable products. Gradually during the present century, the public generally has become more aware of the potential of continuously cropping the forest, and provincial governments have passed legislation and promulgated regulations to provide for protecting existing forests, particularly against fire, and for growing new crops as the timber is cut. Most provinces themselves provide protection.

Responsibility for scientific forest management has been less clear. In most cases the tenure of the lessee or licencee has been on a year-to-year basis, and he has had no inclination to spend money on establishing a crop which he might not be allowed to harvest and on which he would have to pay full stumpage dues anyway if he were still around to cut it. Except in the case of timber sales, stumpage dues have been fixed by statute or regulation without reference to the cost of regeneration and subsequent crop tending. The owner of the land, the provincial government, on the other hand, has claimed that the stumpage fees have been insufficient to pay the costs of forest protection and other administration in the province, and that the money which should have gone for regeneration has been siphoned off by the Federal Government in its corporation income tax. For its part, the Federal Government has had no jurisdiction over provincial land.

Over the past few years there has been developing a marked change in public attitudes. One large province has itself assumed the full responsibility for regenerating its cutover lands following logging, and has launched a major action program to accomplish this in cooperation with its lessees and licencees. Another province has classified its forest lands according to growth potential, 
and is setting its rental fees accordingly. Thus the lessee practising good forestry will be rewarded by increased production for the same fees. A third large timbered province, where recent major expansions have caused the forest industries to compete strongly for the available timber supplies, has been enforcing its allowable annual cut provisions very strictly so that the lessee or licensee may increase his cut only after proving that he has increased the annual growth on his limit sufficiently to meet it. Indeed most provinces have required management plans and have set allowable annual cuts for some time, but such restrictions encourage improved cutting and forestry practices only when they curtailed desired expansion.

Canada is known throughout the world for the wealth and variety of its wildlife. And as with the timber, the harvestable surplus of game and fur in Canada's forests has seldom been fully utilized, despite an estimated million and a half hunters and two and a half million fishermen. However, number of hunters have increased by $25 \%$ in five years and fishermen by $50 \%$.

Even more startling has been the numerical increase rate of outdoor recreationists as a group; numbers have tripled in the past decade. The numerous lakes, both large and small, with which the forests are interspersed, the abundant rivers and streams, the forests bordering the shores of two oceans, the hills and mountains and winter climate so adaptable to ski runs amid attractive forest surroundings, have made Canada a national and international playground for millions of people.

Canada's National Park System alone, begun in 1885 and now containing nearly 20 million acres, each year entertains more than 10 million visitors. Four out of five of these visitors are from Canada itself. Timber cropping is excluded from these areas and they are preserved in their natural state for the benefit and enjoyment of the public. Various facilities are provided to make them accessible and to provide for the comfort of the visitors. "Natural state" and "enjoyment of the public" are not necessarily entirely compatible, so that even here there are conflicts to resolve among the various users.

The provinces have established many types of regional parks, camping, picnic and roadside parks or recreation centres, historic sites, public fishing and hunting areas, a few wilderness areas and sometimes forest reserves operated as parks. Probably the total of such areas either developed or under development exceeds fifty million acres, but they vary in size from a few acres to hundreds of thousands. Similarly some are operated as singleuse areas, while others serve many purposes, including that of timber production. There is also an increasing use by recreationists of crown lands leased or licensed primarily for timber production. The degree of development and the policies of administration differ widely among the provinces and even between different types of area within the same province. Here again there is a fruitful field for the forest land manager to try to reach a happy balance among the conflicting demands upon the specific areas under his control.

Canada's forests, then, play a major role both in the economy of the nation and the environment-for-living of its people. The wood and paper industries, already accounting for a fourth of the value of the country's exports and ranking among the leading manufacturing industries in value of factory shipments, value added by manufacture and salaries and wages 
paid, are looking to phenomenal expansion in the years ahead. At the same time, recreational use of the forests is exploding. Tourist dollars spent by Canadians must be many times the third to half a billion dollars which United States tourists are now spending annually in Canada. And every year many millions of Canadian dollars are spent on hunting and fishing equipment, on ski equipment and on cameras and films.

Surely then, forest management in Canada has an exciting future. 